\title{
Activation of the symbiosis of free nitrogen-fixing bacteria with plants by an additional influx of photosynthesis products to the roots \\ Chikov V.I., Akhtyamova G.A., Khamidullina L.A.
}

Kazan Institute of Biochemistry and Biophysics of FRC Kazan Scientific Center of RAS, Kazan, Russia

\author{
E-mail:vichikov@bk.ru
}

\begin{abstract}
Key message. An in vivo technology is proposed that enhances the export of assimilates from leaves to roots. The possibility of thus increasing the mass of the roots and the formation of additional nitrogen in the soil-plant system is shown.

Keywords: photosynthesis, regulation, root growth, microorganisms
\end{abstract}

Long-term studies of photosynthesis allowed the authors to identify the mechanism of regulation of this process at the level of the leaf and the whole plant. An extracellular enzyme, acid invertase, has proven to be a key regulatory element. When V. I. Chikov, G. A. Akhtyamova, S. N. the primary products of $\mathrm{CO}_{2}$ absorption (organic acids) in chloroplasts do not completely turn into sugars, they enter the extracellular space and activate invertase, which hydrolyzes the transport product of photosynthesis - sucrose. The hydrolysis products in the apoplast increase the concentration of osmotic substances, which closes the stomata. As a result, the ratio of light and dark processes in chloroplasts becomes balanced. During these studies, complex compounds of metals $(\mathrm{Cu}$ and $\mathrm{Zn})$ with ammonia (ammoniates) were found, which, after spraying the plants, alkalizing the medium in the leaf apoplast, suppress invertase, which enhances photosynthesis and export of sugars from the leaf. It was shown that spraying plants with ammonia $\left(10^{-4} \mathrm{M}\right)$ increases the yield and root mass, which is accompanied by the appearance of additional nitrogen in the soil-plant system. This additional nitrogen increases with a decrease in the amount of mineral nitrogen fertilizers introduced into the soil. The scheme is such that, under certain conditions, fertilizers can be dispensed with altogether. Options are proposed for developing methods for growing plants without fertilizers by increasing the role of microorganisms. Experiments were demonstrated on a standard modernized seeder SZS-3.6, which made it possible to double the number of shoots and the mass of the plant while reducing the amount of fertilizer by a factor of three.

\section{Активация симбиоза свободных азотфиксирующих бактерий с растениями путем дополнительного притока продуктов фотосинтеза к корням \\ Чиков В.И., Ахтямова Г.А., Хамидуллина Л.А}

Казанский институт биохимии и биофизики ФИЦ КазНЦ РАН

\begin{abstract}
Аннотация. Предлагается технология іп vivo, которая увеличивает экспорт ассимилятов от листьев к корням. Показана возможность увеличения массы корней и образования дополнительного азота в системе почва-растение. Ключевые слова: фотосинтез, регуляичи, рост корней, микроорганизмы
\end{abstract}

Многолетние исследования фотосинтеза позволили авторам выявить механизм регуляции этого процесса на уровне листа и всего растения. Внеклеточный фермент, кислая инвертаза, оказался ключевым регуляторным элементом. Когда первичные продукты поглощения $\mathrm{CO}_{2}$ (органические кислоты) в хлоропластах неполностью превращаются в сахара, они попадают во внеклеточное пространство и активируют инвертазу, которая гидролизует транспортный продукт фотосинтеза-сахарозу. Продукты гидролиза в апопласте увеличивают концентрацию осмотических веществ, которая закрывает устьица. В результате соотношение световых и темновых процессов в хлоропластах становится сбалансированным. В ходе этих исследований были обнаружены комплексные соединения металлов (Сu и $\mathrm{Zn})$ с аммиаком (аммиакаты), которые после опрыскивания растений, подщелачивая среду в апопласте листьев, подавляют инвертазу, что усиливает фотосинтез и экспорт сахаров из листьев. Было показано, что опрыскивание растений аммиакатами $\left(10^{-4} \mathrm{M}\right)$ увеличивает урожайность и корневую массу, что сопровождается появлением дополнительного азота в системе почва-растение. Этот дополнительный азот увеличивается с уменьшением количества минеральных азотных удобрений, вносимых в почву. Схема такова, что при определенных условиях можно полностью отказаться от удобрений. Предложены варианты разработки методов выращивания растений без удобрений за счет повышения роли микроорганизмов. Эксперименты были продемонстрированы на стандартной модернизированной сеялке СЗС3.6, которая позволила удвоить количество побегов и массу растения при одновременном снижении количества удобрений в три раза.

Чиков В.И., Ахтямова Г.А., Баташева С.Н., Михайлов А.Л., Хамидуллина Л.А., Тимофеева О.А. Влияние блокирования гена апопластной инвертазы на фотосинтез в растениях томата // Физиология растений, 2015, том 62, № 1, c. 45-51.

Chikov V.I. The Participation of Apoplast Invertase in the Regulation of Photosynthesis by Stomatal Mechanism. Journal of Plant Sciences 2017; 5(5): 134-145 http://www.sciencepublishinggroup.com/j/jps doi: 10.11648/j.jps.20170505.12 ISSN: 2331-0723 (Print); ISSN: 2331-0731 (Online).

Чиков В.И., Ахтямова Г.А., Пахомова В.М. Противоречие между существующей агротехникой и эволюционным развитием растений должно быть устранено // Доклады ТСХА Вып. 291, (часть 11). Москва. Издат. РГАУ_МСХА. 2019г. С.386- 391. 